\title{
Analysis of Gas Leakage and Current Loss of Solid Oxide Fuel Cells by Screen Printing
}

Jia, Chuan; Han, Minfang; Chen, Ming

Published in:

E C S Transactions

Link to article, DOI:

$10.1149 / 07801.1533$ ecst

Publication date:

2017

Document Version

Peer reviewed version

Link back to DTU Orbit

Citation (APA):

Jia, C., Han, M., \& Chen, M. (2017). Analysis of Gas Leakage and Current Loss of Solid Oxide Fuel Cells by Screen Printing. E C S Transactions, 78(1), 1533-1540. https://doi.org/10.1149/07801.1533ecst

\section{General rights}

Copyright and moral rights for the publications made accessible in the public portal are retained by the authors and/or other copyright owners and it is a condition of accessing publications that users recognise and abide by the legal requirements associated with these rights.

- Users may download and print one copy of any publication from the public portal for the purpose of private study or research.

- You may not further distribute the material or use it for any profit-making activity or commercial gain

- You may freely distribute the URL identifying the publication in the public portal

If you believe that this document breaches copyright please contact us providing details, and we will remove access to the work immediately and investigate your claim. 


\title{
Analysis of gas leakage and current loss of solid oxide fuel cells
}

\author{
by screen printing
}

\author{
Chuan Jia ${ }^{\mathrm{a}}$, Minfang $\operatorname{Han}^{*}{ }^{\mathrm{a}, \mathrm{b}}$, Ming Chen ${ }^{\mathrm{c}}$ \\ a. State Key Laboratory of Power Systems, Department of Thermal Engineering, \\ Tsinghua University, Beijing, 100084, P.R. China \\ b. Tsinghua Innovation Center in Dongguan, Dongguan, 523808, P.R. China \\ c. Department of Energy Conversion and Storage, Technical University of Denmark, \\ Fredrikborgsvej 399, P.O. Box 49, DK-4000 Roskilde, Denmark
}

Two types of anode supported solid oxide fuel cell (SOFC) NiOYSZ/YSZ/GDC/LSCF with the same structure and different manufacturing process were tested. Gas leakage was suspected for cells manufactured with screen printing technique. Effective leak current densities for both types of cells were calculated. Their performances of electrochemical impedance spectroscopy (EIS) were compared and distribution function of relaxation times (DRT) technique was also used to find the clue of gas leakage. Finally, thinning and penetrating holes were observed in electrolyte layer, which confirmed the occurrence of gas leakage.

\section{Introduction}

Solid oxide fuel cell (SOFC) is a new kind of energy conversion device, which can directly convert chemical energy to electricity [1]. SOFCs are especially suitable for combined heat and power systems and on mobile power systems, such as portable computers, mobile telephones, and military communication equipment [2]. During applications, working parameters are important for SOFCs, among which gas leakage is worth to be considered. Not only will the fuel efficiency decrease, but the gas leaked from cells may mix with oxygen outside and leads to explosion at high temperatures in test rigs, which becomes a big safety problem. Therefore, increased attention has been paid on gas leakage during cell testing.

Ideally, the electrolyte between the anode and cathode in SOFC should be absolutely densified, which means the porosity of the electrolyte layer should be zero. However, small pores in electrolyte cannot be avoided. If small pores are connected, electrolyte will be penetrated, leading to internal gas leakage between anode and cathode side, which significantly reduces the performance of cells. 
In practice, special test rigs are often especially established for testing of gas leakage of SOFCs [3-5]. It can detect gas leakage with high precision. However, it is time-consuming and cannot give feedback during fuel testing in test rigs. Rasmussen et al. introduced a method of gas leakage calculation by measuring partial pressure of anode and cathode side. In this paper, this method was used with additional analysis of EIS. DRT was also calculated for analysis of cell behavior. Two types of anodesupported planar SOFC with same structure and different manufacturing procedures were adopted for their performances test.

\section{Experimental}

As mentioned above, two types of anode-supported planar SOFC were tested, namely Cell A and Cell B. The manufacturing procedure of Cell A was described in Ref. [6]. The cell consisted of a $\mathrm{NiO} / \mathrm{YSZ}$ anode support $(300 \mu \mathrm{m})$, an active $\mathrm{NiO} / \mathrm{YSZ}$ anode $(15 \sim 20 \mu \mathrm{m})$, a dense YSZ electrolyte film $(10 \mu \mathrm{m})$, a GDC barrier layer at cathode side $(10 \mu \mathrm{m})$ and a LSCF porous cathode $(20 \mu \mathrm{m})$. Cell B had the same structure as Cell A. The main difference between the two types of cells was the manufacturing technique. The electrolyte layer of Cell A was fabricated by screen printing, while the electrolyte layer of Cell B was fabricated by isostatic pressing described in Ref. [7]. The active area of both types of cells were $4 \mathrm{~cm} \times 4 \mathrm{~cm}$. The cells were tested in the same test setup mentioned in Ref. [8]. Partial pressure of oxygen was measured during test by $p_{\mathrm{O}_{2}}$ sensors, which were placed in the gas inlet, anode side and gas outlet. The other side of $p_{\mathrm{O}_{2}}$ sensors was exposed in air with constant flow, in which the partial oxygen pressure was constantly at $0.21 \mathrm{~atm}$.

NiO-YSZ anode was reduced at $850{ }^{\circ} \mathrm{C}$ in safety hydrogen $(9 \%$ hydrogen in nitrogen) for at least $2 \mathrm{~h}$ before testing until cell voltage became stable. After that, the cell characterization and electrochemical measurement procedures were executed at $850{ }^{\circ} \mathrm{C}, 800{ }^{\circ} \mathrm{C}, 750{ }^{\circ} \mathrm{C}$ and $700{ }^{\circ} \mathrm{C}$ supplied with $24 \mathrm{~L} / \mathrm{h}$ hydrogen with $4 \%, 20 \%$ and $50 \%$ steam content to NiO-YSZ anode and $140 \mathrm{~L} / \mathrm{h}$ air to GDC-LSCF cathode. The minimum voltage applied in $\mathrm{i}-\mathrm{V}$ test was limited to $700 \mathrm{mV}$ for the protection of test cells. Electrochemical impedance spectroscopy (EIS) of test cells was measured at zero DC current with Solatron 1260 frequency analyzer and external shunt in series with the test cell. 12 points per decade was recorded from $96,850 \mathrm{~Hz}$ to $0.08 \mathrm{~Hz}$. Analysis of impedance data by DRT method was carried out using Ravdav [9]. To check the leak change with gas supply, variable flow rates of hydrogen $(5 \sim 30 \mathrm{~L} / \mathrm{h})$ and air $(8 \sim 170 \mathrm{~L} / \mathrm{h})$ were also used. At last, microstructure of cross sections of Cell A was observed using TM3000 Telescope (Hitachi Ltd., Japan). 


\section{Results and discussion}

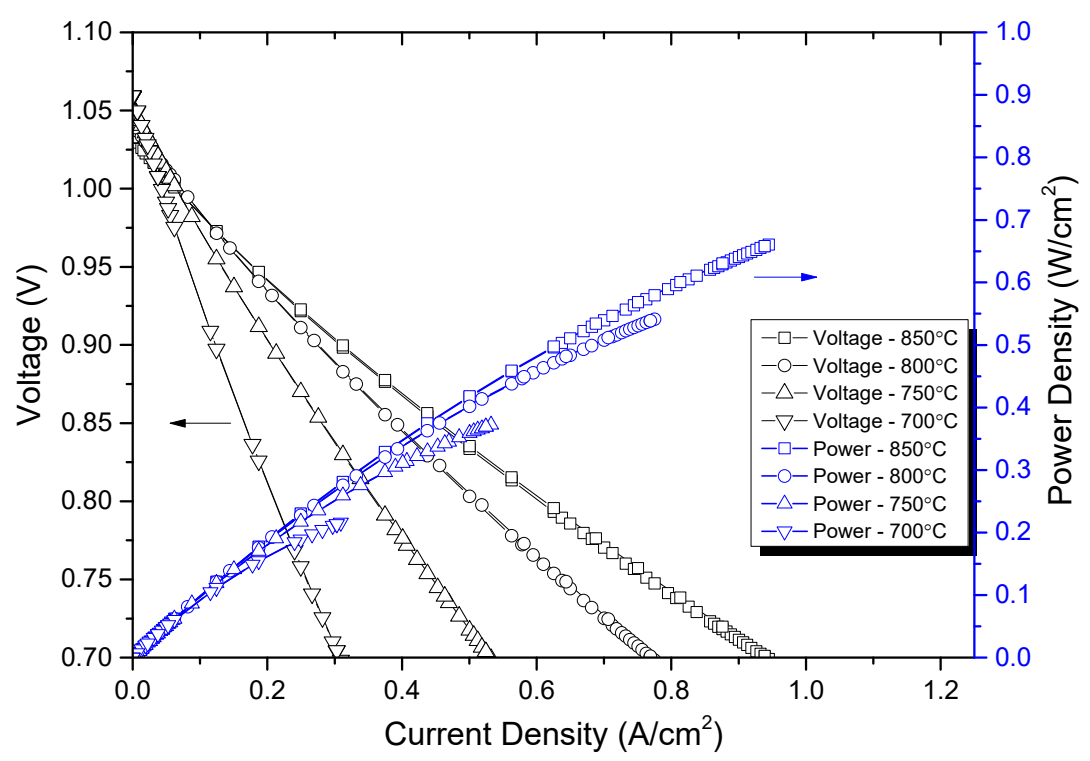

Fig. 1 Performance of Cell A at different temperatures with 4\% steam humidified hydrogen supplied to anode side

\section{$\underline{\text { Cell characterization }}$}

Fig. 1 and Fig. 2 show the i-V curves at different temperatures from $850{ }^{\circ} \mathrm{C}$ to 700 ${ }^{\circ} \mathrm{C}$ with $4 \%$ steam humidified hydrogen. As shown, the performance of Cell B was obviously better than Cell A. The open circuit voltages (OCVs) of Cell A reached 1.032 $\mathrm{V}, 1.042 \mathrm{~V}, 1.052 \mathrm{~V}$ and $1.059 \mathrm{~V}$ at $850{ }^{\circ} \mathrm{C}, 800{ }^{\circ} \mathrm{C}, 750{ }^{\circ} \mathrm{C}$ and $700{ }^{\circ} \mathrm{C}$, respectively, with maximum power density of $0.660 \mathrm{~W} \mathrm{~cm}^{-2}, 0.541 \mathrm{~W} \mathrm{~cm}^{-2}, 0.372 \mathrm{~W} \mathrm{~cm}^{-2}$ and 0.216 $\mathrm{W} \mathrm{cm}{ }^{-2}$ in sequence. For Cell $\mathrm{B}$, the open circuit voltages rose to $1.054 \mathrm{~V}, 1.064 \mathrm{~V}$, $1.074 \mathrm{~V}$ and $1.083 \mathrm{~V}$ at $850{ }^{\circ} \mathrm{C}, 800^{\circ} \mathrm{C}, 750^{\circ} \mathrm{C}$ and $700{ }^{\circ} \mathrm{C}$, respectively, with maximum power density of $0.826 \mathrm{~W} \mathrm{~cm}^{-2}, 0.600 \mathrm{~W} \mathrm{~cm}^{-2}, 0.379 \mathrm{~W} \mathrm{~cm}^{-2}$ and $0.219 \mathrm{~W} \mathrm{~cm}^{-2}$ in sequence. Around $20 \mathrm{mV}$ difference in OCVs between Cell A and B at the same testing conditions raised the doubt of possibility of gas leakage in Cell A. 
Next, OCV losses compared with theoretical values at different temperatures and fuel compositions were calculated for both types of cells in Fig. 3 and Fig. 4. The OCV losses of Cell A were approximately doubled at every test condition compared with Cell B. Besides, the OCV loss of test cells were very sensitive to the change of steam content in hydrogen supplied to anode side. Meanwhile, negligible changes happened when temperatures varied, indicating that the occurrence of OCV losses were dominated by temperature-independent procedures in cells.

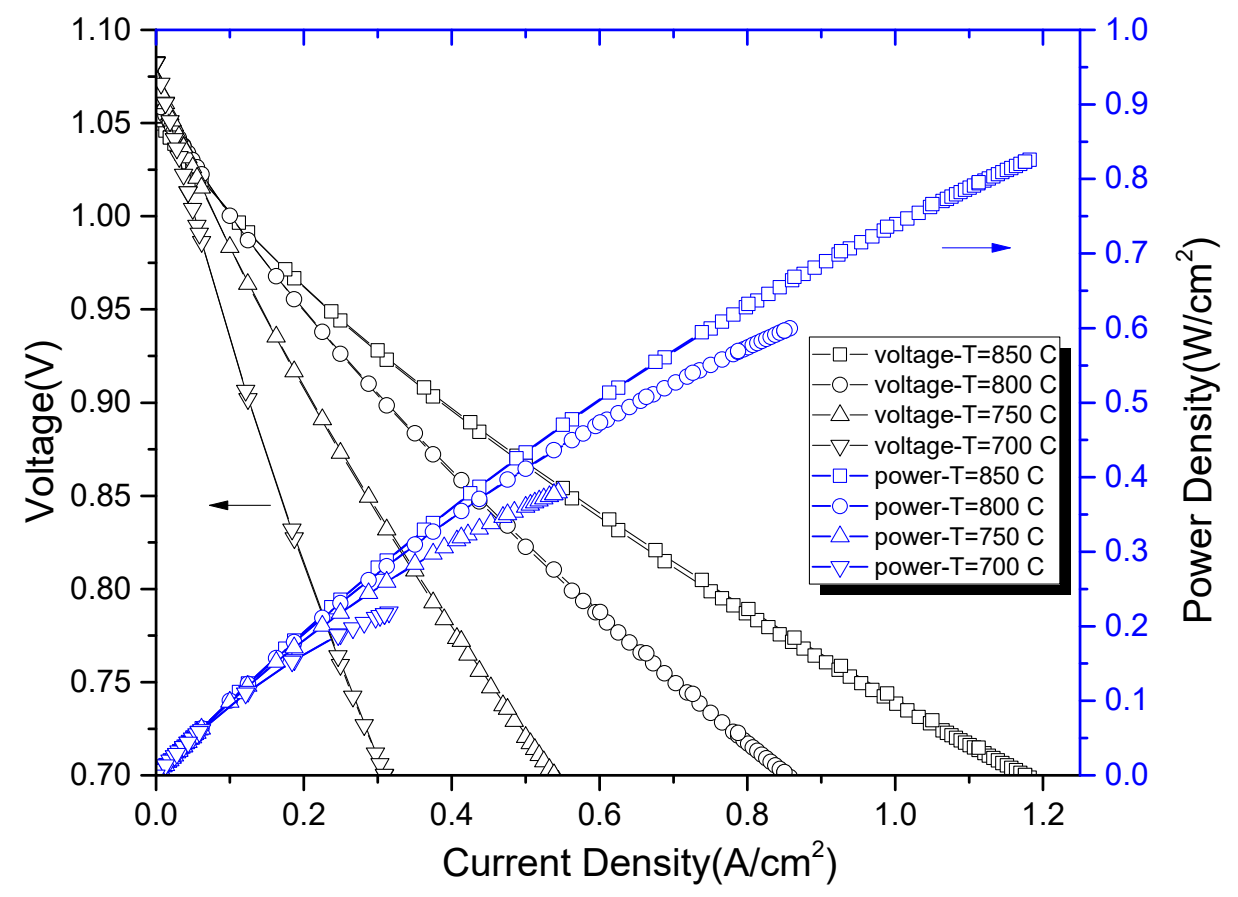

Fig. 2 Performance of Cell B at different temperatures with 4\% steam humidified hydrogen supplied to anode side 


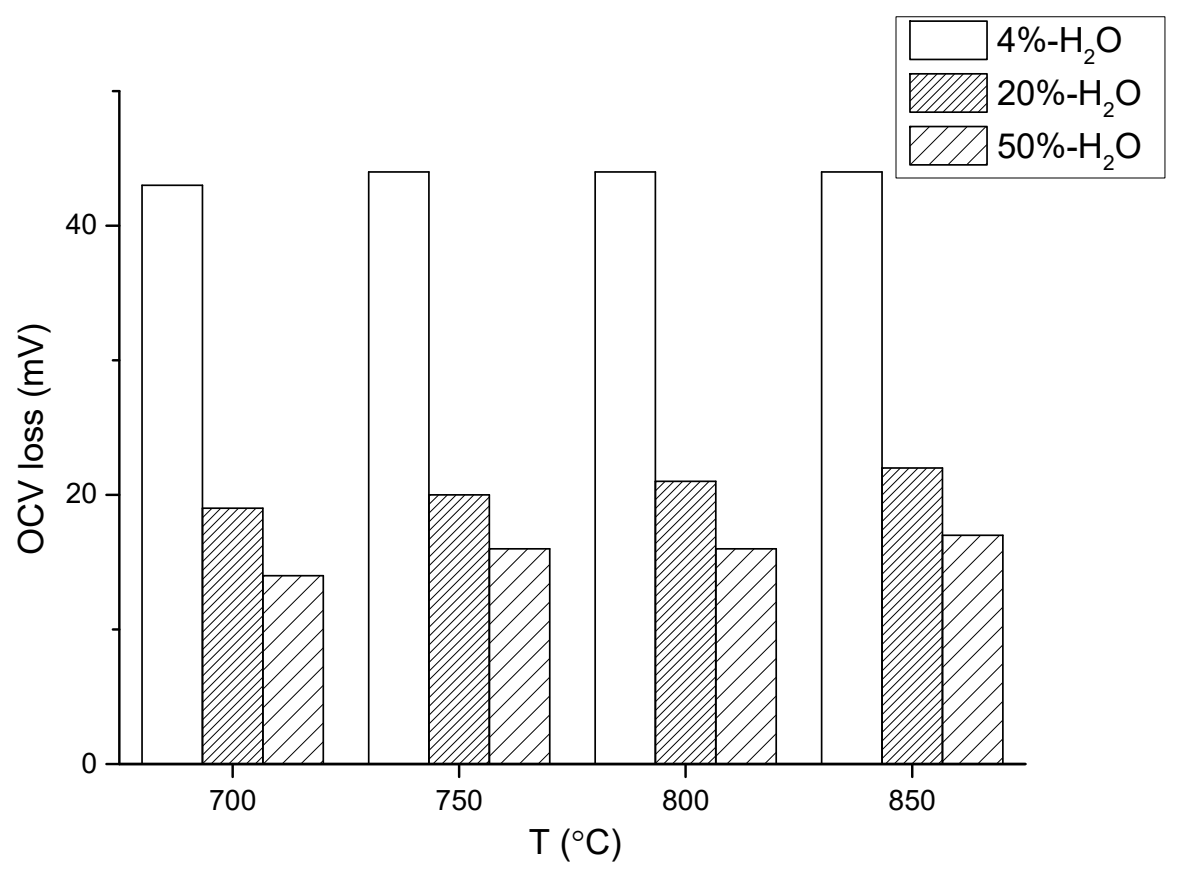

Fig. 3 OCV loss of Cell A at different test conditions

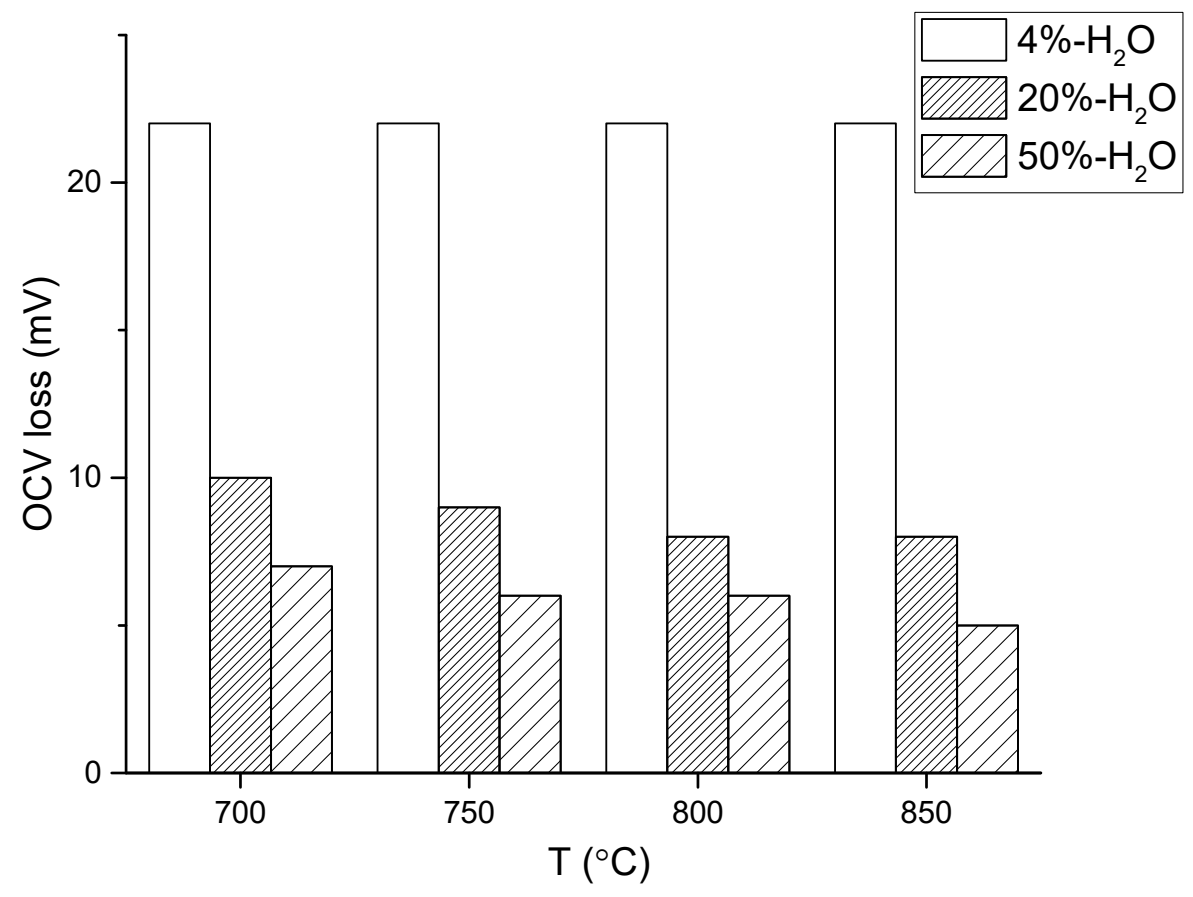

Fig. 4 OCV loss of Cell B at different test conditions

$\underline{\text { Gas leakage calculation }}$ 


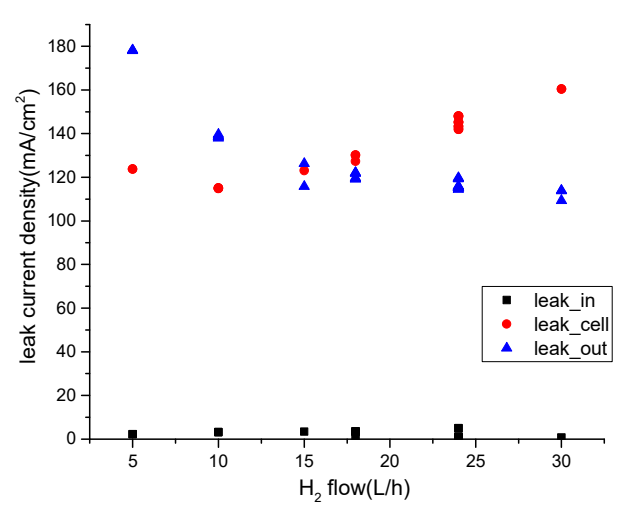

(a)

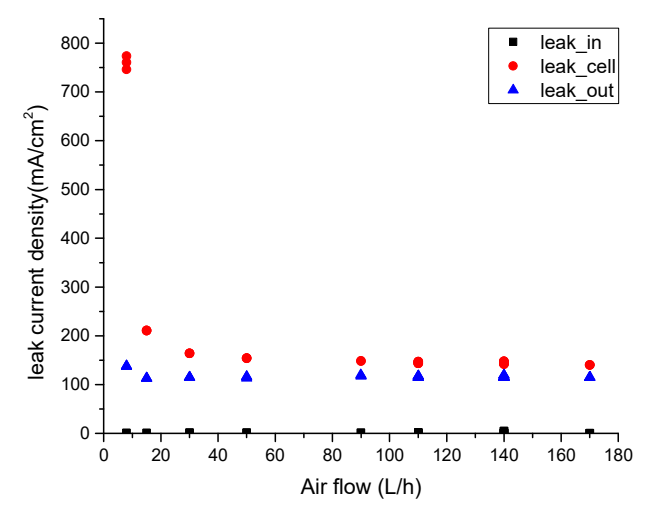

(b)

Fig. 5 Leak current density of Cell A

(a) at constant air flow rate $(140 \mathrm{~L} / \mathrm{h})$; (b) at constant $\mathrm{H}_{2}$ flow rate $(24 \mathrm{~L} / \mathrm{h})$

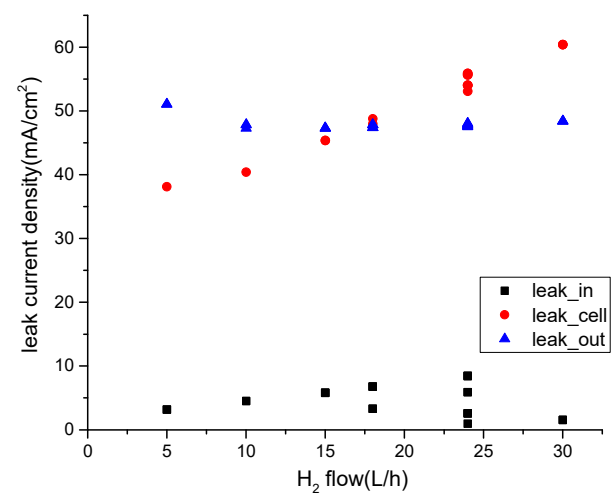

(a)

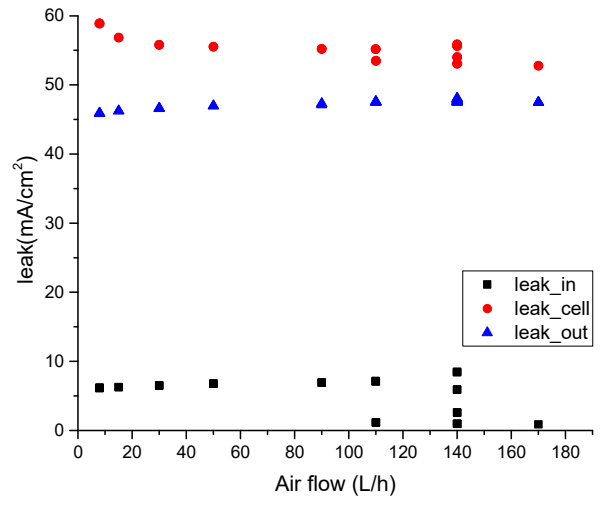

(b)

Fig. 6 leak current density of Cell B

(a) at constant air flow rate $(140 \mathrm{~L} / \mathrm{h})$; (b) at constant $\mathrm{H}_{2}$ flow rate $(24 \mathrm{~L} / \mathrm{h})$

According to Ref. [10], if gas leakage occurs in test cell, the influences of $\mathrm{N}_{2}$ to anode and $\mathrm{H}_{2}$ to cathode are both negligible in comparison with the influence of $\mathrm{O}_{2}$ to anode, because it can significantly increase the partial oxygen pressure in anode side which should be kept in a very low value. Formulas in ref. [10] were adopted in this paper for the calculation of effective leak current, in which full responsibility of gas leakage to OCV loss was hypothesized. The results are shown in Fig. 5 and Fig. 6. Leaks at inlet in both cells were negligible, indicating good sealing conditions in cell testing. However, two to three times of leak current density was calculated for Cell A as Cell B. Furthermore, leak current density was almost constant with the change of air flow at cathode side except for extremely small flow rate, while it raised in cell with the increase of $\mathrm{H}_{2}$ flow rate at anode side.

\section{Electrochemical measurement}




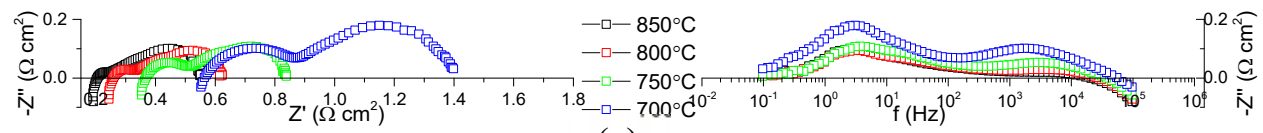

(a)

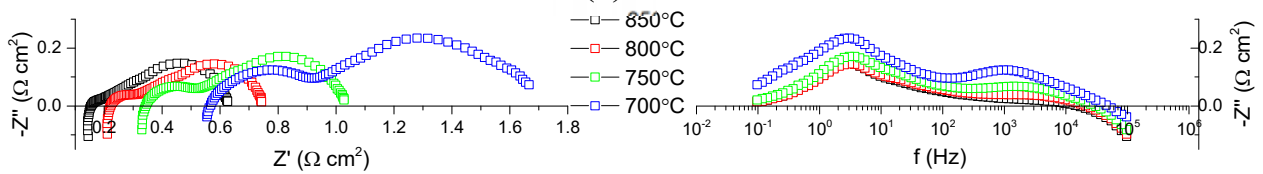

(b)

Fig. 7 EIS results of test cells at different temperatures with $4 \%$ steam humidified hydrogen supplied to anode side

(a) Cell A; (b) Cell B

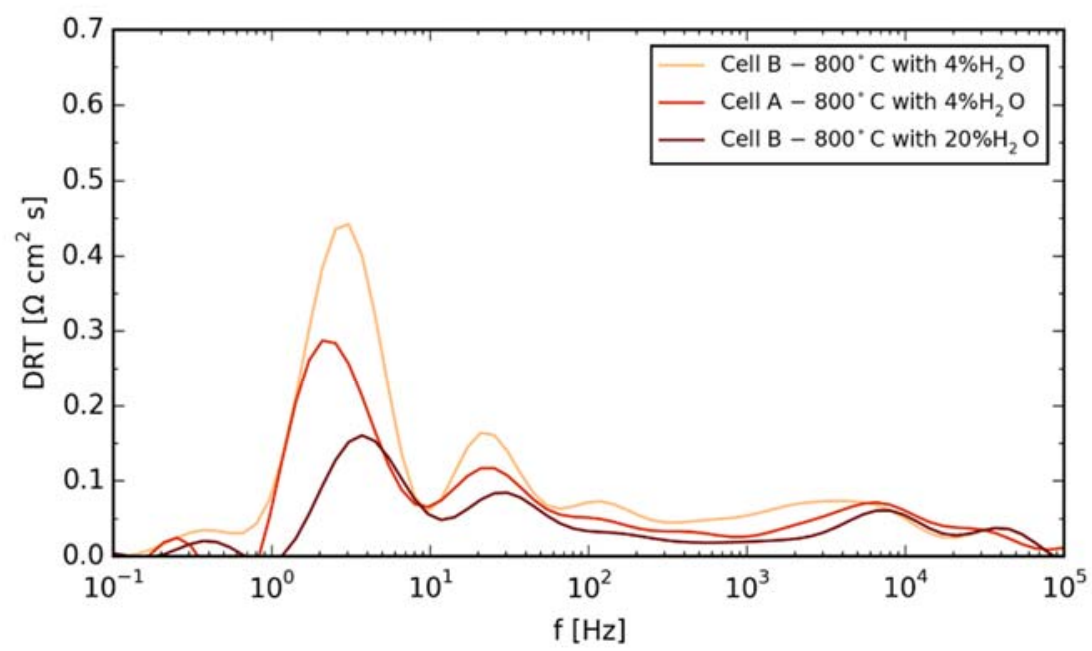

Fig. 8 DRT analysis of EIS data of Cell A and B at $800^{\circ} \mathrm{C}$ with different fuel components supplied to anode side

Fig. 7 shows the EIS results of Cell A and Cell B at different temperatures with $4 \%$ steam humidified hydrogen. Ohmic resistances of two cells were almost the same at the same condition as expected, while polarization resistances of Cell A were smaller, with $0.36,0.37,0.49$ and $0.85 \Omega \mathrm{cm}^{2}$ at $850{ }^{\circ} \mathrm{C}, 800{ }^{\circ} \mathrm{C}, 750{ }^{\circ} \mathrm{C}$ and $700{ }^{\circ} \mathrm{C}$, respectively. The corresponding polarization resistance of Cell B were $0.48,0.53,0.70,1.11 \Omega \mathrm{cm}^{2}$. If gas leakage happened in Cell A, steam content in anode side increased equivalently, which had the effect on decreasing polarization resistance.

Fig. 8 shows the DRT analysis of EIS data of Cell A and B at $800^{\circ} \mathrm{C}$. As we can see, the result line of Cell $\mathrm{A}$ at $800^{\circ} \mathrm{C}$ with $4 \%$ steam humidified $\mathrm{H}_{2}$ lay between results lines of Cell B at $800{ }^{\circ} \mathrm{C}$ with $4 \%$ and $20 \%$ steam-contained $\mathrm{H}_{2}$, which means that an additional steam content was equivalently added to the anode side of Cell A. That corresponds to the features of hypothesis of gas leakage of Cell A. 
$\underline{\text { SEM image of test cell }}$

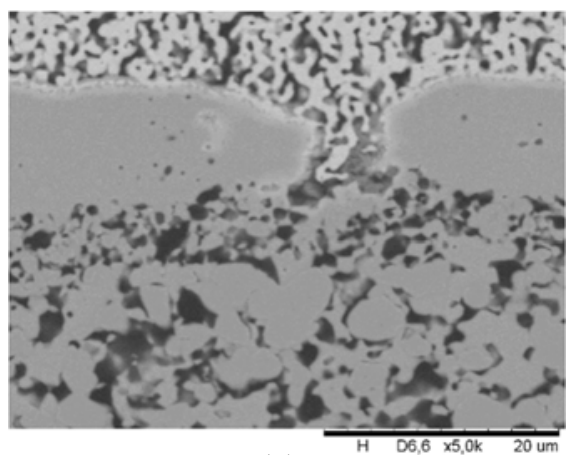

(a)

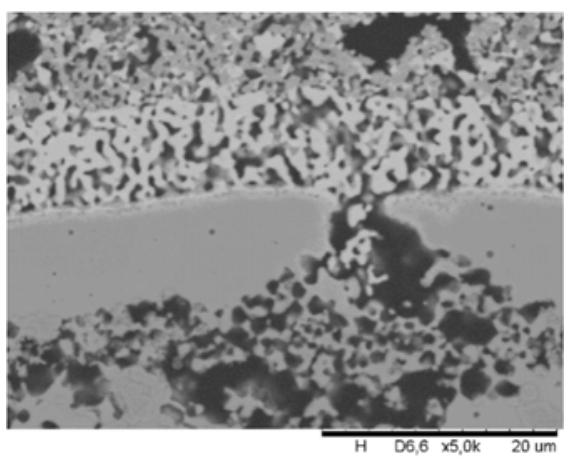

(c)

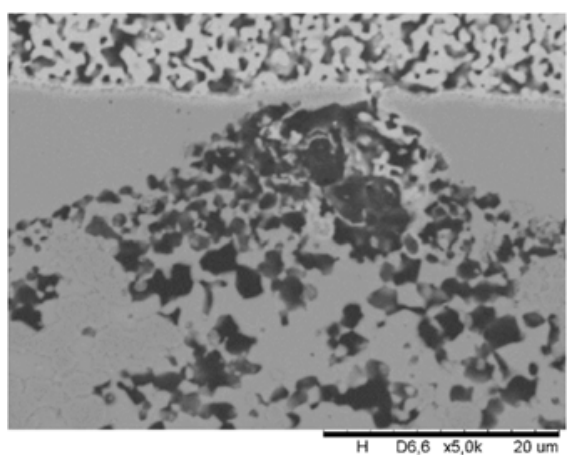

(b)

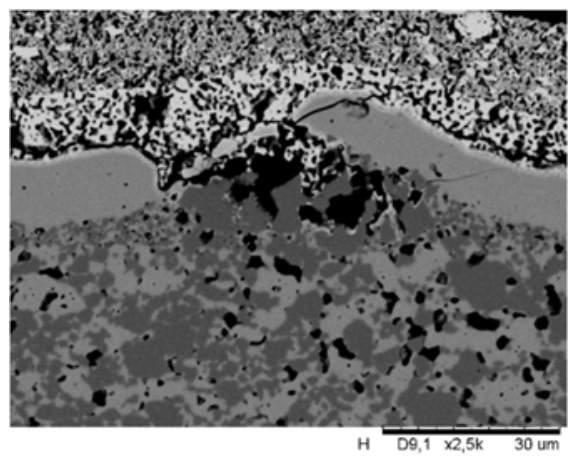

(d)

Fig. 9 SEM image of defects in the electrolyte layer of Cell A after testing

Cross sections of Cell A after testing were observed after polishing using SEM. Several defects in the electrolyte layer were found. According to Fig. 9, thinning (Fig. 9-(a)), small holes of around $2 \mu \mathrm{m}$ (Fig. 9-(b)(c)) and large holes of around $10 \mu \mathrm{m}$ (Fig. 9-(d)) in diameter can be found in the electrolyte layer of Cell A. The penetrating holes certainly led to gas leakage inside test cells. The amount of such defects was expected to be relatively small, as the test cell of Type A could still be working in a steady state and no gigantic drop of voltage and power was observed.

\section{Conclusion}

Cell characterization and electrochemical measurement were performed for two types of NiO-YSZ/YSZ/GDC/LSCF anode supported SOFC. Gas leakage in Cell A was suspected and calculated with the data of partial oxygen pressure measured from the gas inlet, anode side and gas outlet. Several clues of gas leaks were analyzed and finally observed with the assistance of SEM.

Although the discussion above is not quite accurate compared with results from specifically designed gas leakage test setups, it shows a simple way for gas leakage detection during cell testing at low cost, which is quite meaningful during the application of SOFC. 


\section{Acknowledgements}

This work is supported by Beijing Training Project for the Leading Talents in S \&

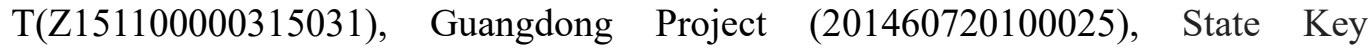
Laboratory of Power Systems at Tsinghua University (No. SKLD15Z02, No. SKLD16Z11), One-Hundred Leading Talents Development Project for Progress on Science and Technology of Beijing (No. 20152121363), and Coal-based Key Scientific and Technological Project from The Shanxi Science and Technology Department (No. MD2014-08). We would like to thank the staff of Department of Energy Conversion and Storage, Technical University of Denmark for the support of cell testing.

\section{References}

[1] Y. Zhao, C. Xia, L. Jia, et al. International Journal of Hydrogen Energy, 38 (36), 16498 (2013).

[2] J. Larminie, A. Dicks, M.S. McDonald. Fuel cell systems explained. Vol. 2. Chichester, UK: J. Wiley, 2003: 22-23.

[3] M. Bram, S. Reckers, P. Drinovac, et al. Journal of Power Sources 138 (1), 111-119 (2004).

[4] Z. Lü, R. Wang, X. Huang, et al. Solid State Ionics, 179 (27), 1286-1290 (2008).

[5] N.H. Menzler, V.A.C. Haanappel. Journal of power sources 195 (16), 5340-5343 (2010).

[6] H. Fan, M. Keane, P. Singh, et al. Journal of Power Sources 268, 634 (2014): 634639.

[7] Z. Liu, Z. Zheng, M. Han, et al. Journal of Power Sources, 195 (21) 7230-7233 (2010)

[8] M. Mogensen, P.H. Larsen, P.V. Hendriksen, et al. in: S.C. Singhal, M. Dokiya (Eds.), Solid Oxide Fuel Cells (SOFC VI), Electrochemical Society Inc., Pennington, pp. 904-915 (1999).

[9] C. Graves, RAVDAV Data Analysis Software, Version 0.9.7, 2012.

[10] J.F.B. Rasmussen, P.V. Hendriksen, A. Hagen, et al. Fuel Cells, 8 (6), 385-393 (2008). 